\title{
SYMPTOMATIC INTRADISCAL VACUUM PHENOMENON
}

\author{
FENÔMENO DE VÁCUO INTRADISCAL SINTOMÁTICO \\ FENÓMENO DE VACIOO INTRADISCAL SINTOMÁTICO \\ Pedro luis Bazán, ${ }^{1,2}$ Richard Alejandro Avero González, ${ }^{1,2}$ Nicolás Maximiliano Ciccioli, ${ }^{1,2}$ Álvaro Enrique Borri, ${ }^{1,2}$ Martín Medina ${ }^{1,2}$ \\ 1. HIGA San Martín La Plata, La Plata, Buenos Aires, Argentina. \\ 2. Hospital Italiano La Plata, La Plata, Buenos Aires, Argentina.
}

\begin{abstract}
Objective: Intradiscal vacuum phenomenon (IVP) is a common finding in the study of degenerative disc disease. Discogenic low back pain can be manifested in different ways, including irradiation to the lower limbs. This study aims to acknowledge the complementary studies used to diagnose IVP, determine their sensitivity, and assess the correlation between clinical and imaging findings. Methods: This is a descriptive, observational and prospective study involving clinical and imaging evaluation of 100 patients with IVP, using dynamic and plain radiographs, computed tomography and magnetic resonance imaging. The factors of analysis include sex, age, reason for consultation, visual analogue scale, irradiation and topography of the pain, the existence of sciatica and claudication, smoking status, and body mass index. Results: The overall average age of the patients was 64.6 years, who particularly evidence degenerative pathology. IVP was observed in 99 CT, 85 dynamic radiographs, 80 plain radiographs and 65 nuclear magnetic resonance images (MRI). Conclusion: The most useful studies for diagnosing the vacuum disc phenomenon are plain and dynamic radiographs, tomography, and magnetic resonance. The CT is the most sensitive imaging study for IVP detection, followed by dynamic radiographs obtained during extension. A correlation was observed between older age, overweight, and IVP. Level of evidence IV; Case-series.
\end{abstract}

Keywords: Intervertebral disc degeneration; Intervertebral disc; Low back pain.

\section{RESUMO}

Objetivo: O fenômeno do vácuo intervertebral (FVI) é um achado comum no estudo da doença degenerativa do disco. A dor lombar discogênica pode se manifestar de diferentes formas, incluindo a irradiação para os membros inferiores. O presente estudo pretende reconhecer os estudos complementares utilizados para diagnosticar o FVI, determinar sua sensibilidade e avaliar a correlação entre os achados clínicos e de imagem. Métodos: Estudo descritivo, observacional e prospectivo envolvendo a avaliação clínica e por imagem de 100 pacientes com FVI, utilizando radiografias simples e dinâmicas, tomografia computadorizada e ressonância magnética. Os fatores da análise incluem sexo, idade, motivo da consulta, escala visual analógica, irradiação e topografia da dor, existência de ciatalgia e claudicação, tabagismo e índice de massa corporal. Resultados: A idade média geral dos pacientes foi de 64,6 anos, evidenciando particularmente a patologia degenerativa. O FVI foi observado em 99 tomografias computadorizadas, 85 radiografias dinâmicas, 80 radiografias simples e 65 ressonâncias magnéticas nucleares (RM). Conclusão: Os estudos mais úteis para detectar FVI são as radiografias simples e dinâmicas, a tomografia e a ressonância magnética. A tomografia computadorizada é o exame de imagem mais sensível para a detecção do FVI, seguido pelas radiografias dinâmicas obtidas durante a extensão. Observou-se uma correlação entre a idade avançada, sobrepeso e o fenômeno do vácuo intervertebral. Nível de evidência IV; Série de casos.

Descritores: Degeneração do disco intervertebral; Disco intervertebral; Dor lombar.

\section{RESUMEN}

Objetivo: El fenómeno del vacío intervertebral (FVI) es un hallazgo común en el estudio de la enfermedad degenerativa del disco. El dolor lumbar discogénico puede manifestarse de diferentes maneras, incluyendo la irradiación para los miembros inferiores. El presente estudio pretende reconocer los estudios complementarios utilizados para diagnosticar el FVI, determinar su sensibilidad y evaluar la correlación entre los hallazgos clínicos y de imagen. Métodos: Estudio descriptivo, observacional y prospectivo involucrando la evaluación clínica y por imagen de 100 pacientes con FVI, utilizando radiografías simples y dinámicas, tomografía computarizada y resonancia magnética. Los factores de análisis incluyen sexo, edad, motivo de consulta, escala visual analógica, irradiación y topografía del dolor, existencia de ciatalgia y claudicación, tabaquismo e índice de masa corporal. Resultados: La edad promedio general de los pacientes fue de 64,6 años, evidenciando particularmente la patología degenerativa. El FVI fue observado en 99 tomografías computadorizadas, 85 radiografías dinámicas, 80 radiografías simples y 65 resonancias magnéticas nucleares (RM). Conclusión: Los estudios más útiles para diagnosticar FVI son las radiografías simples y dinámicas, la tomografía y la resonancia magnética. La tomografía computadorizada es el estudio de imagen más sensible para la detección de FVI, seguido por las radiografías dinámicas obtenidas durante la extensión. Se observó una correlación entre la edad avanzada, sobrepeso y el fenómeno de vacío intervertebral. Nivel de evidencia IV; Serie de casos.

Descriptores: Degeneración del disco intervertebral; Disco intervertebral; Dolor de la región lumbar. 


\section{INTRODUCTION}

Intervertebral vacuum phenomenon is a common finding in the study of degenerative disc disease. ${ }^{1}$ Considered the last stage of disc degeneration, ${ }^{2}$ it is often the cause of low back pain. ${ }^{3}$ Low back pain associated with disc degeneration can present with a wide variety of symptoms ranging from benign to unbearable low back pain, and may include radicular pain in the lower limbs. ${ }^{4}$

A classic study by Gershon-Cohen ${ }^{5}$ found the vacuum phenomenon in radiographs of $21 \%$ of 130 asymptomatic elderly patients (Figure 1).

Larde et al. ${ }^{6}$ report that at least one disc-level degenerative disease is observed in $12 \%$ of plain radiographs and $40 \%$ of computed tomography (Figure 2) scans of the lumbar spine in patients aged over 40 years.

In a study of patients with degenerative spinal disease, intervertebral vacuum phenomenon (IVP) remains grossly underreported. ${ }^{7}$

The aims of the present study are to acknowledge the complementary studies used to diagnose IVP, determine their sensitivity, and assess the correlation between clinical and imaging findings.

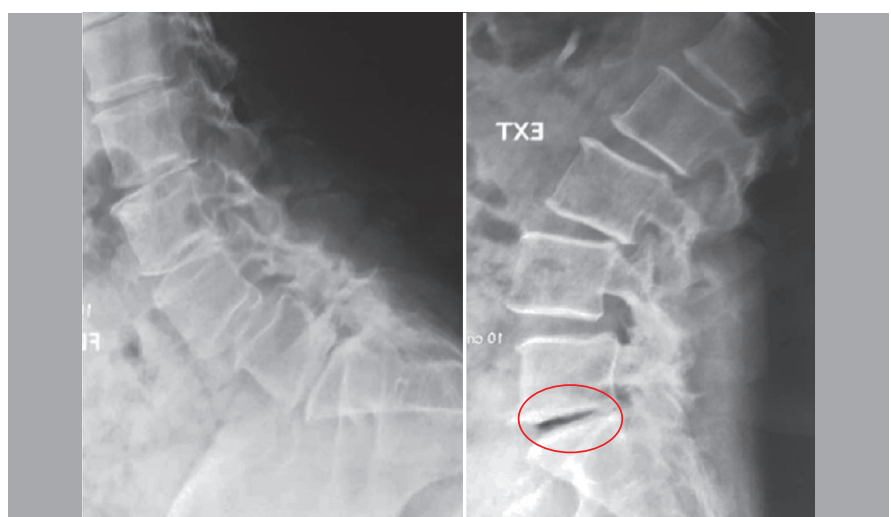

Figure 1. X-rays in flexion and extension, in the areas where the vacuum phenomenon is evidenced in the fifth disc space by increasing the space, with the difference of the annulus fibrosis.

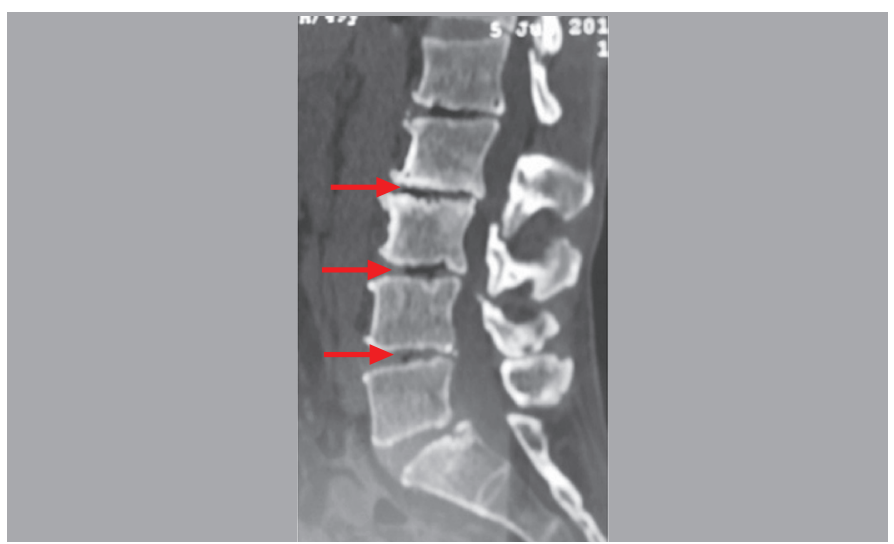

Figure 2. Sagittal section of the Multi Slice Tomography showing vacuum phenomenon in the first 4 lumbar discs.

\section{METHODS}

A descriptive, observational and prospective study was designed for all patients who attended consultations at the two hospitals where this study was conducted due to degenerative lumbar pathology. Among 100 patients studied, vacuum disc phenomenon was observed in at least one study.

The exclusion criteria comprised sacralization of the fifth lumbar vertebra, traumatic and infectious pathology, and previous lumbar surgery.

The data were collected considering sex, age, reason for consultation, visual analogue scale, irradiation and topography of the pain, the existence of sciatica and claudication, smoking status, and body mass index.

The imaging studies requested for the patients with IVP were AP view radiographs and maximum extension-flexion radiographs of the lumbosacral spine, MRI and CT. A digital imaging record was kept for subsequent analyses.

The analysis of 500 lumbar disc segments found multi- and mono-segmental degenerative disc disease in 100 patients. The analysis also helped to determine the presence of Modic type changes in the studied segments. ${ }^{8}$

All patient data were gathered in a table specially designed for this purpose, and analyzed using statistical data collection software (Microsoft Excel ${ }^{\circledR}$ ).

\section{RESULTS}

Of the total patients, 64 were women and 36 were men. The average age was 64.6 years (ranging from 33 to 92 years).

In 99 out of the 100 patients, IVP was observed in the CT (221 disc spaces). The IVP was mono-segmental in 42 patients and multisegmental in 57 patients. Consequently, CT is the most sensitive study for diagnosing vacuum disc phenomenon. Among the other studies, IVP was observed in plain radiographs (131 disc spaces), 85 dynamic radiographs (158 disc spaces in extension) and $65 \mathrm{MRI}$ scans (Figure 3 ) of 80 patients.

Considering the reasons for consultation, 49 patients presented lumbosciatic pain (36 with unilateral pain), 43 presented low back pain without irradiation to the lower limbs, and 5 presented lumbocrural pain.

Claudication pain was present in 40 patients, and the number of patients who were current or former smokers was also 40 . The average body mass index was 29.15. Scoliosis was diagnosed in 35 patients. Of the 64 patients with pain of 6 points or higher on the visual analogue scale (VAS), 39 presented multiple IVP (60.91\%). In the present study, it was determined that T2 in MRI provides better information compared to the $\mathrm{T} 1$ relaxation parameter, as it shows the IVP with greater precision (Hypointensity marked).

\section{DISCUSSION}

Fick ${ }^{9}$ first observed the presence of gas within the intervertebral disc space while he was studying joints under traction. It was first named "vacuum phenomenon" by Magnusson ${ }^{10}$ in 1937, without attributing any clinical significance. In 1942, Knutsson ${ }^{11}$ correlated vacuum phenomenon with disc degeneration for the first time. In 1946, Gershon-Cohenil ${ }^{5}$ referred to the phenomenon as "the phantom nucleus pulposus" when observing radiolucent areas within the interbody space found in lumbar plain radiographs.

The vacuum phenomenon is a gas collection that may originate in the intervertebral disc (Figure 3). It is relatively frequent in radiographs of patients with lumbar degenerative disease. ${ }^{12,13}$ This phenomenon is considered the last stage of disc degeneration, and is often the cause of low back pain. ${ }^{3}$ The vacuum is composed of approximately $90 \%$ nitrogen and small amounts of oxygen or carbon dioxide. ${ }^{14}$

Since the introduction of CT scans, this method has become

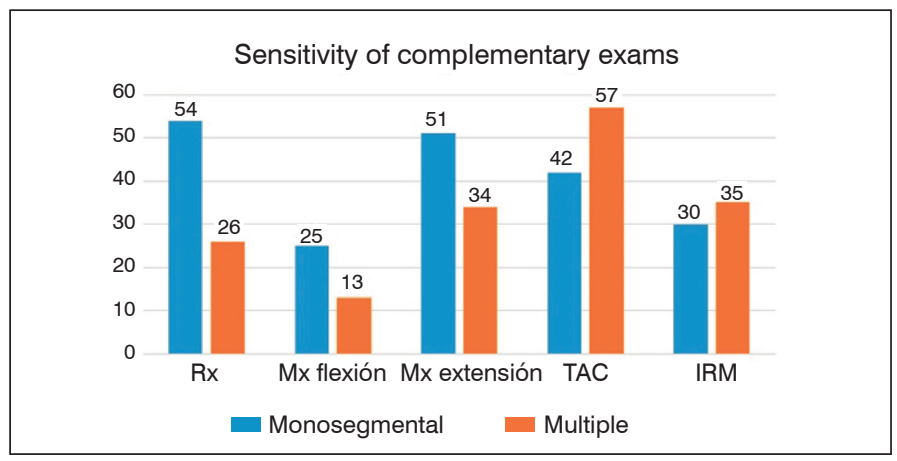

Figure 3. Diagnosis of Vacuum Disc Phenomenon. 
popular due to its sensitivity. ${ }^{6}$ It is the most sensitive study for detecting IVP, followed by dynamic radiographs obtained during extension. ${ }^{15}$ The least sensitive study is the radiograph in flexion, due to the reduced disc space height and the lesser fiber strain on the annulus fibrosus.

MRI provides better information on disc pathology by showing a more precise delineation of the anatomy. ${ }^{1,16,17}$

The intervertebral disc undergoes age-related changes, resulting in disc degeneration over the course of lifetime. ${ }^{4,18}$

Degenerative disc disease is usually considered a sign of intervertebral instability, and requires treatment. ${ }^{19}$ Hence the importance of a precise diagnosis.

Many authors mention the endplates as one of the components of the intervertebral disc, due to the important role they play in disc disease..$^{3,4}$

The pathogenesis of IVP is debatable and is most likely multifactorial. The prevailing hypothesis for gas formation in a degenerative disc is based on the endplate-degeneration theory. The endplates provide nutrition for the disc through a porous surface, while preventing disc protrusion into the vertebral bodies. As the vertebral endplates degenerate, the hyaline cartilage becomes calcified, and inflammatory cytokines are produced. This combination blocks the nutritional pathways, which results in metabolic imbalance and decreased synthesis of structural matrix proteins. As a result, the structural integrity of the disc becomes unstable, and the continuous compression-and-distraction motion creates a cleft that is gradually filled with gas. ${ }^{3}$
Some publications present a relationship between IVD and weather changes, e.g. that of Morishita et al., who associate IVP with low back pain in the mornings and when standing up. Low back pain may also be influenced by changes in the weather. ${ }^{20,21}$

Kasai et al. report that patients with IVP in the lumbar intervertebral disc experienced a worsening of low back pain when the atmospheric pressure was decreased. ${ }^{13}$

Many publications associate the presence of IVP with compression radiculopathy, as the gas occupies the space created by the clefts in the nucleus pulposus within the intervertebral disc, causing disc protrusion. ${ }^{22-27}$

\section{CONCLUSION}

The most useful studies for the diagnosis of vacuum disc phenomenon in patients with lumbar degenerative disc disease are plain and dynamic radiographs, computed tomography, and magnetic resonance.

Computed tomography with sagittal reconstruction is the most sensitive imaging study for IVP detection, followed by dynamic radiographs during extension.

A correlation was observed between advanced age, overweight, and IVP.

All authors declare no potential conflict of interest related to this article.

CONTRIBUTION OF THE AUTHORS: Each author made significant individual contributions to this manuscript. BPL (0000-0003-0060-6558*: work planning, bibliographic support control, results control, discussion of conclusions and final edition. AGR (0000-0001-9489-5615)*: bibliographic review, data management, discussion of conclusions and final draft. BAE (0000-0002-5568-867X)* and MM (0000-0002-5281-5645)*: discussion of conclusions and primary edition. CNM (0000-0002-5851-2821)*: technical details, discussion of the conclusions and primary edition. ${ }^{*}$ ORCID (Open Researcher and Contributor ID).

\section{REFERENCES}

1. D'Anastasi M, Birkenmaier C, Schmidt GP, Wegener B, Reiser M, Baur-Melnyk A. Correlation Between Vacuum Phenomenon on CT and Fluid on MRI in Degenerative Disks. AJR Am J Roentgenol. 2011;197(5):1182-9.

2. Fardon DF, Milette PC. (2001) Nomenclature and Classification of Lumbar Disc Pathology: Recommendations of the Combined Task Forces of the North American Spine Society, American Society of Spine Radiology, and American Society of Neuroradiology. Spine (Phila Pa 1976). 2001;26(5):E93-113.

3. Li FC, Zhang N, Chen WS, Chen QX. Endplate degeneration may be the origination of the vacuum phenomenon in intervertebral discs. Med Hypotheses. 2010;75(2):169-71.

4. Madigan L, Vaccaro AR, Spector LR, Milam RA. Management of Symptomatic Lumbar Degenerative Disk Disease. J Am Acad Orthop Surg. 2009;17(2):102-11.

5. Gershon-Cohen J. The phantom nucleus pulposus. Am J Roentgenol Radium Ther. 1946;55:43-8.

6. Larde D, Mathieu D, Frija J, Gaston A, Vasile N. Spinal vacuum phenomenon: CT diagnosis and significance. J Comput Assist Tomogr. 1982;6(4):671-6.

7. Yen CP, Beckman JM, Vivas AC, Bach K, Uribe JS. Effects of intradiscal vacuum phenomenon on surgical outcome of lateral interbody fusion for degenerative lumbar disease. J Neurosurg Spine. 2017;26(4):419-25.

8. Modic MT, Steinberg PM, Ross JS, Masaryk TJ, Carter JR. (1988). Degenerative disk disease: Assessment of changes in vertebral body marrow with MR imaging. Radiology. 1988;166(1 Pt 1):193-9.

9. Fick R. Handbuch del' anatomie und Mechanik der Gelenke. Berlin: Verlag der Wissenschaften:1910.

10. Magnusson W. Uber die bendingungen des Hervortretens der wirklichenGelenkspalte auf demrontgenbilde. Acta Radiol. 1937:18:733-41.

11. Knutsson F. The vacuum phenomenon in the intervertebral discs. Acta Radiol. 1942:23:173-9.

12. An KC, Kong GM, Park DH, Baik JM, Youn JH, Lee WS. Comparison of Posterior Lumbar Interbody Fusion and Posterolateral Lumbar Fusion in Monosegmental Vacuum Phenomenon within an Intervertebral Disc. Asian Spine J. 2016;10(1):93-8.

13. Kasai $Y$, Takegami K, Uchida A. Change of barometric pressure influences low back pain in patients with vacuum phenomenon within lumbar intervertebral disc. J Spinal Disord Tech. 2002;15(4):290-3
14. Ford LT, Gilula LA, Murphy WA, Gado M. Analysis of gas in vacuum lumbar disc. Am J Radiol. 1977:128(6):1056-7.

15. Coulier B. The spectrum of vacuum phenomenon and gas in spine. JBR-BTR. 2004;87(1):9-16

16. Schweitzer ME, El-Noueam KI. Vacuum disc: frequency of high signal intensity on T2weighted MR images. Skeletal Radiol. 1998:27(2):83-6.

17. Grenier N, Grossman R, Schiebler M, Yeager B, Goldberg H, Kressel H. Degenerative lumbar disk disease: pitfalls and usefulness of MR imaging in detection of vacuum phenomenon Radiology. 1987;164(3):861-5.

18. Christian WA, Pfirrmann AM, Zanetti M, Hodler J, Boos N. Magnetic Resonance Classification of Lumbar Intervertebral Disc Degeneration. Spine (Phila Pa 1976). 2001;26(17):1873-8.

19. Yoshiiwa T, Miyazaki M, Notani N, Ishihara T, Kawano M, Tsumura H. Analysis of the relationship between ligamentum flavum thickening and lumbar segmental instability, disc degeneration, and facet joint osteoarthritis in lumbar spinal stenosis. Asian Spine J. $2016 ; 10(6): 1132-40$.

20. Morishita K, Kasai Y, Uchida A. Clinical symptoms of patients with intervertebral vacuum phenomenon. Neurologist. 2008;14(1):37-9.

21. Ayberk G, Özveren M, Yildrim T. Spinal gas accumulation causing lumbar discogenic disease: a case report. Acta Orthop Traumatol Turc. 2015;49(1):103-5.

22. Belfquih H, El Mostarchid B, Akhaddar A, Gazzaz M, Boucetta M. Sciatica caused by lumbar epidural gas. Pan Afr Med J. 2014;18:162.

23. Yun SM, Suh BS, Park JS. Symptomatic Epidural Gas-containing Cyst from Intervertebral Vacuum Phenomenon. Korean J Spine. 2012;9(4):365-8.

24. Lee C, Cho J, Hyun S, Yoon S, Kim K, Kim H. Symptomatic gas containing herniated disc with the vacuum phenomenon: mechanism and treatment. Neurol Med Chir (Tokyo). 2012;52(2):106-8.

25. Choi K, Kim J, Lee S. Surgical experience of gas containing disk herniation. Neurol Med Chir (Tokyo). 2010;50(10):905-9

26. Sasani M, Ozer F, Oktenoglu T, Cosar M, Karaarslan E, Sarioglu A. Recurrent Radiculopathy Caused by Epidural Gas After Spinal Surgery. Spine (Phila Pa 1976). 2007:32(10):E320-5.

27. Pierpaolo L, Mastronardi L, Puzzilli F, Missori P. Gas-containing lumbar disc herniation. Spine (Phila Pa 1976). 1993;18(16):2553-36 